\title{
Protein Counting in Single Cancer Cells
}

Stephanie M. Schubert, ${ }^{\dagger}$ Stephanie R. Walter, ${ }^{\dagger}$ Mael Manesse, and David R. Walt ${ }^{*}$

Department of Chemistry, Tufts University, Medford, MA, 02155, USA

${ }^{\dagger}$ These authors contributed equally to this work

*Correspondence: david.walt@tufts.edu

\section{Table of Contents}

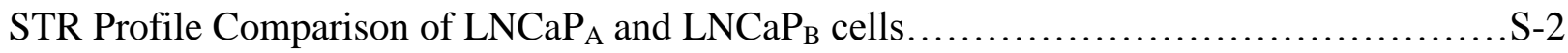

Representative bright field images of a single $\mathrm{LNCaP}_{\mathrm{B}}$ cell inside a $1 \mu \mathrm{L}$ droplet............ S-2

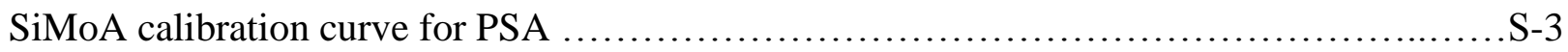

Linear fit of PSA content in low cell counts of $\mathrm{LNCaP}_{\mathrm{A}}$ and $\mathrm{LNCaP}_{\mathrm{B}}$ cells.................. 
Supplementary Table 1. STR Profile Comparison of $\mathrm{LNCaP}_{\mathrm{A}}$ and $\mathrm{LNCaP}_{\mathrm{B}}$ cells

\begin{tabular}{ccc}
\hline Loci & LNCaP $_{\mathrm{A}}$ & LNCaP $_{\mathrm{B}}$ \\
\hline D5S818 & 11,12 & 11,12 \\
D13S317 & 10,12 & 10,13 \\
D7S820 & $9.1,10.3$ & $8,8.1,9,9.1$ \\
D16S539 & 11 & 11,12 \\
vWA & 16,18 & 16,18 \\
THO1 & 9 & 9 \\
AMEL & $\mathrm{X}, \mathrm{Y}$ & $\mathrm{X}, \mathrm{Y}$ \\
TPOX & 8,9 & 8,9 \\
CSF1PO & 10,11 & 10,12 \\
\hline \% match to & 100 & 88 \\
ATCC cat\# & & \\
CRL-1740 & &
\end{tabular}

A

B
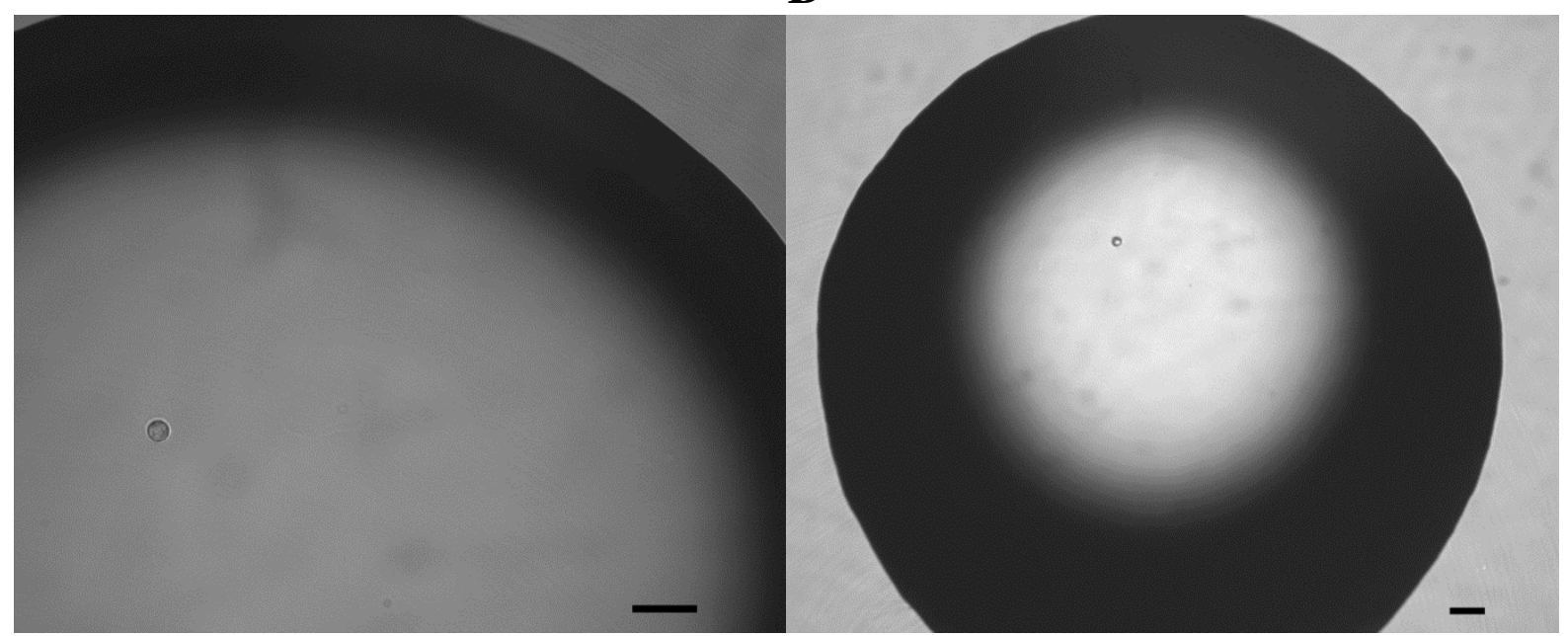

Supplementary Figure 1. Representative bright field images of a single $\mathrm{LNCaP}_{\mathrm{B}}$ cell inside a 1 $\mu \mathrm{L}$ droplet visualized at A) $10 \mathrm{x}$ and B) $5 \mathrm{x}$ magnification. Scale bars are $50 \mu \mathrm{m}$. 


\section{B}

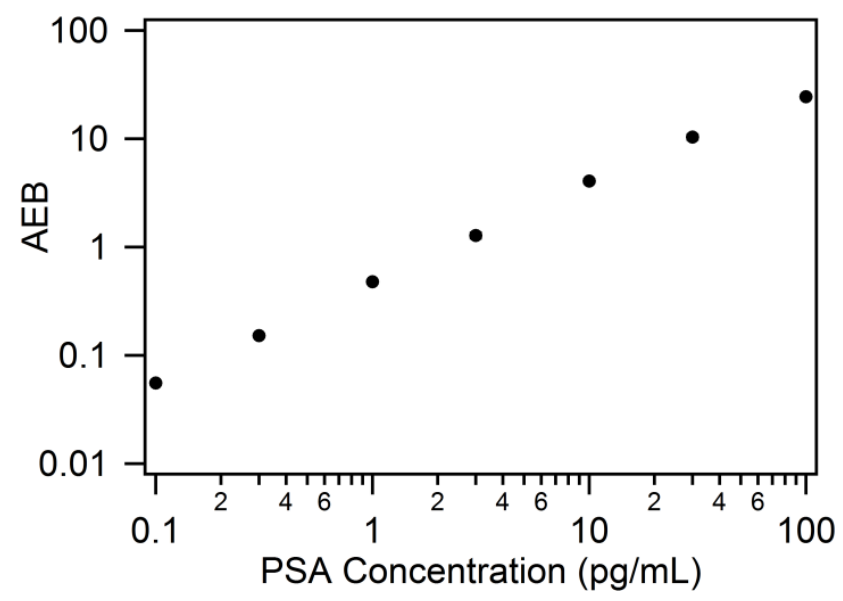

\begin{tabular}{ccc}
\hline $\begin{array}{c}\text { PSA conc. } \\
\text { (pg/mL) }\end{array}$ & $\begin{array}{c}\text { Average } \\
\text { AEB }\end{array}$ & $\begin{array}{c}\text { Standard } \\
\text { deviation }\end{array}$ \\
\hline 0 & 0.0068 & 0.0005 \\
0.1 & 0.056 & 0.002 \\
0.3 & 0.152 & 0.005 \\
1 & 0.478 & 0.006 \\
3 & 1.28 & 0.07 \\
10 & 4.1 & 0.1 \\
30 & 10.4 & 0.5 \\
100 & 24.4 & 0.6 \\
\hline
\end{tabular}

Supplementary Figure 2. A) SiMoA calibration curve for PSA plotted on a log-log scale. Error bars are contained within data points and represent $n=3$ measurements. The assay LOD of 0.0043 $\pm 0.0022 \mathrm{pg} / \mathrm{mL}$ was calculated by extrapolating the background PSA concentration plus 3 standard deviations of the background using a 4-parameter logistic fit. B) Tabulated values for typical PSA calibration curve.

A

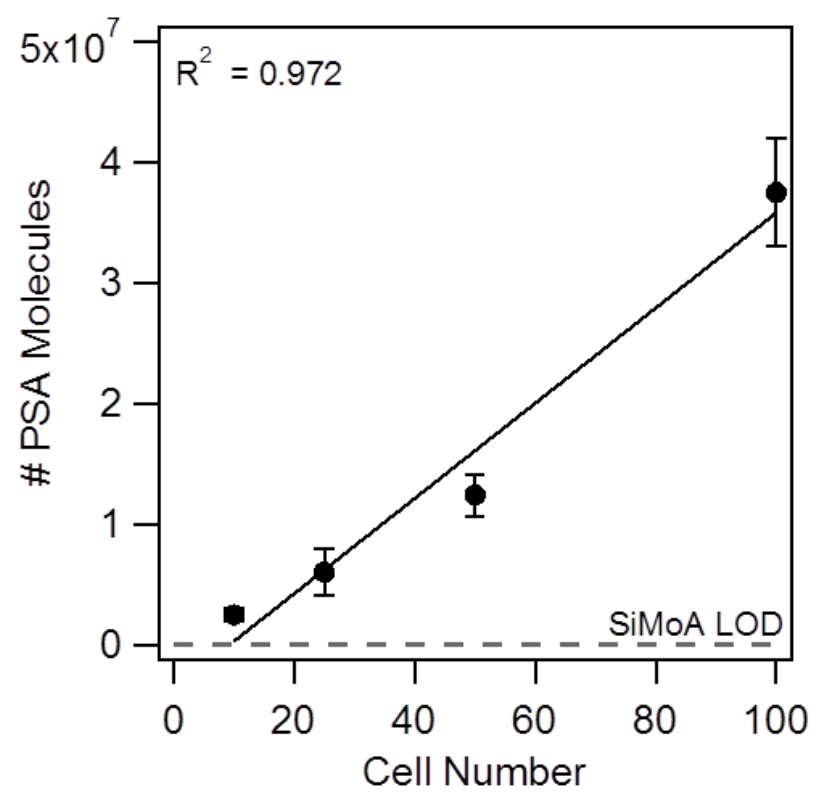

B

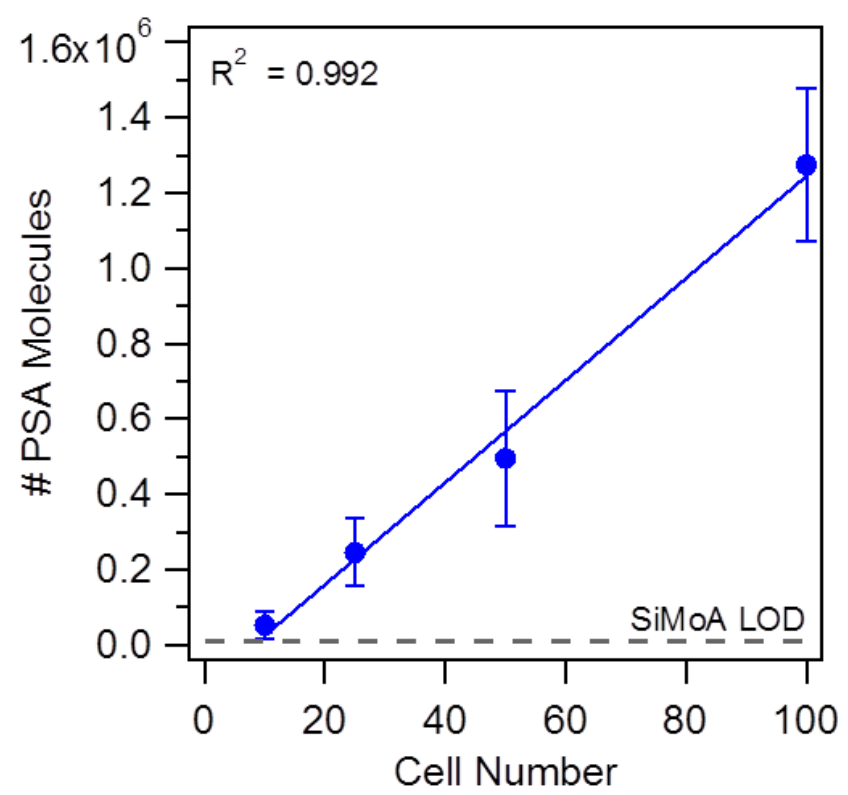

Supplementary Figure 3. Linear fit of PSA content in low cell counts of A) $\mathrm{LNCaP}_{\mathrm{A}}$ and B) $\mathrm{LNCaP}_{\mathrm{B}}$ cells. Cell numbers $(10,25,50$, and 100) were estimated via serial dilution. Error bars represent the standard deviation from eight replicate measurements. 